south-western part of the continent in the neighbourhood of Cape Town; it amounts to an increase of southerly dip of $8^{\prime}$ a year. The line of no change passes through Madagascar; east of that there is a decrease of southerly dip. The annual change in the horizontal intensity shows a decrease in absolute magnitude towards the north; over the greater part of the Union it has a value of from $80 \gamma$ to $100 \gamma$ yearly, and is a decrease.

\section{BOOKS RECEIVED.}

Historical Sketches of Old Charing. By Dr. J. Galloway. Pp. 82. (London: John Bale, Ltd.) Ios. $6 d$. net.

Le Musée d'Histoire Naturelle Moderne. Sa Mission, son Organisation, ses Droits. By G. Gilson. Pp. xii +256 . (Bruxelles: Académie Royale.)

A First Course in Plant and Animal Biology. By W. S. Furneaux. Pp. viii +232 . (London: University Tutorial Press, Ltd.) $2 s$.

Die Europaeischen Schlangen. By Dr. F. Steinheil. Sechstes Heft. Tafel 26-3o. (Jena: G. Fischer.) 3 marks.

Handbuch der Pharmakognosie. By A. Tschirch. Lief. 35, 36, 37. (Leipzig: C. H. Tauchnitz.) 2 marks each Lief.

Berliner Botaniker in der Geschichte der Pflanzenphysiologie. By G. Haberlandt. Pp. 29. (Berlin : Gebrüder Borntraeger.) I mark.

Grundzüge der Weltpolitik in der Gegenwart. By J. J. Ruedorffer. Pp. xiii +252 . (Stuttgart and Berlin : Deutsche Verlags-Anstalt.)

Principles of Metallurgy. By A. H. Hiorns. Second edition. Pp. xiv +389 . (London: Macmillan and Co., Ltd.) $6 s$.

The Continents and their People. Africa. By J. F. and A. H. Chamberlain. Pp. vii +2 1o. (London: Macmillan and Co., Ltd.) $3^{s}$.

Every Child's Series. How Man Conquered Nature. By M. J. Reynolds. Pp. v+249. (London: Macmillan and Co., Ltd.) Is. $8 d$. net.

The Happy Golfer. By H. Leach. Pp. vii $+4 \mathrm{I} 4$. (London : Macmillan and Co., Ltd.) $6 s$. net.

The School Algebra. By A. G. Cracknell. Pp. viii $+568+1 \times x v i i$. (London: University Tutorial Press, Ltd.) $5 s$.

Pond Problems. By E. E. Unwin. Pp. xvi+i Iq. (Cambridge University Press.) 2s. net.

Handbuch der Morphologie. Edited by A. Lang. Vierter Band. Arthropoda. Vierte Lief. Pp. $42 \mathrm{I}-$ 640. (Jena: G. Fischer.) 5 marks.

Roberts-Austen : a Record of his Work. Compiled and edited by S. W. Smith. Pp. $x+382+x x$ iii plates. (London: C. Griffin and Co., Ltd.) 21 s. net.

Historical Account of Charing Cross Hospital and Medical School. By Dr. W. Hunter. Pp. xxi+309+ xl plates. (London: J. Murray.) $2 \mathrm{I} s$.

County Borough of Halifax. Bankfield Museum Notes. Second series. No. 4. Coptic Cloths. By L. E. Start. Pp. 37. (Halifax: King and Sons.) 2s. $6 d$.

Memoirs of the Geological Survey. England and Wales. The Water Supply of Nottinghamshire from Underground Sources. By G. W. Lamplugh and B.
Smith. Pp. iv $+\mathrm{I} 74$. (London: H. M. Stationery Office.) $5^{s}$.

Memoirs of the Geological Survey. Summary of Progress of the Geological Survey of Great'Britain and the Museum of Practical Geology for I9I3. Pp. iv.t ro7. (London: H.M. Stationery Office.) rs.

\section{CONTENTS.}

PAGE

History and Philosophy of Mathematics . . . 475

Precursors of Christianity. By A. E. Crawley . . 476 Haberlandt's Plant Anatomy. By J. B. F. . . . . 477

Electrotechnics . . . . . . . . . . . . 477

Our Bookshelf . . . . . . . . . . . 478

Letters to the Editor:-

Active Nitrogen.-Prof. H. B. Baker, F.R.S., Dr. Erich Tiede, Hon. R. J. Strutt, F.R.S., Emil Domcke . . . . . . . . . . 478 The Horns of the Okapi.-R. Lydekker, F.R.S. . 478 Thorium Lead--An Unstable Product.-Robert W. Lawson . . . . . . . . . . . 479

Radio-activity and Atomic Numbers.-Dr. A. van den Broek . . . . . . . . . . . . . . . . 480

Seeing and Photographing Very Faintly Illuminated Objects._Prof. P. G. Nutting . . . . . . . 480

June Meteors.-W. F. Denning . . . . . . . . 480 Inorganic "Feeding." (Illustrated.)-Chas. R. Darling .

Experimental Demonstration of an Ampere Molecular Current in a Nearly Perfect Conductor . . 481 Memorial Statue of Capt. Cook. (Illustrated.) . . . $48 \mathrm{r}$ The Wilds of New Zealand. (Illustrated.). . . . . 482 Recent Progress of the Metric System . . . . . 483 Notes . . . . . . . . . . . . . . . . 484 Our Astronomical Column :-

A Faint New Comet (1914c) . . . . . . . . . . . 488

Opposition of Eros (433) this Year . . . . . . 488

Recent Publications of the Allegheny Observatory . . 488

The Variable Satellites of Jupiter and Saturn . . . . 489

Third International Congress of Tropical Agriculture ... . . . . . . . 489

International Commission for Scientific Radiotelegraphic Researches . . . . . . . . . . . 490 The Research Defence Society . . . . . . . . 49r The Synthetic Power of Protoplasm. By E. F. A. 49I Transpiration in Plants. . . . . . . . . . . . . 492 The American Philosophical Society . . . . . . 492 $\mathrm{X}$-Rays and Crystalline Structure. By Prof. W. H.

Bragg, F.R.S. . . . . . . . . . . . . 494 University and Educational Intelligence. . . . . 498 Societies and Academies . . . . . . . . . . . 498 Books Received. . . . . . . . . . . . . . . 500

Editorial and Publishing Offices: MACMILLAN \& CO., LTD.,

ST. MARTIN'S STREET, LONDON, W.C.

Advertisements and business letters to be addressed to the Publishers.

Editorial Communications to the Editor.

Telegraphic Address: Phusis, London.

Telephone Number: GERRARD 8830. 